\title{
Submicron particle mass concentrations and sources in the Amazonian wet season (AMAZE-08)
}

\author{
Q. Chen ${ }^{1, *}$, D. K. Farmer ${ }^{2, * *}$, L. V. Rizzo ${ }^{3}$, T. Pauliquevis ${ }^{3}$, M. Kuwata ${ }^{1, * * *}$, T. G. Karl ${ }^{4, * * * *}$, A. Guenther $^{4, * * * *}$, \\ J. D. Allan ${ }^{5}$, H. Coe ${ }^{5}$, M. O. Andreae ${ }^{6}$, U. Pöschl' ${ }^{6}$, J. L. Jimenez ${ }^{2}$, P. Artaxo ${ }^{7}$, and S. T. Martin ${ }^{1}$ \\ ${ }^{1}$ School of Engineering and Applied Sciences \& Department of Earth and Planetary Sciences, Harvard University, \\ Cambridge, MA, USA \\ ${ }^{2}$ Department of Chemistry and Biochemistry \& Cooperative Institute for Research in Environmental Science, \\ University of Colorado, Boulder, CO, USA \\ ${ }^{3}$ Department of Natural and Earth Sciences, Federal University of São Paulo, Diadema, Brazil \\ ${ }^{4}$ National Center for Atmospheric Research, Boulder, CO, USA \\ ${ }^{5}$ National Centre for Atmospheric Science \& School of Earth, Atmospheric and Environmental Sciences, \\ University of Manchester, Manchester, UK \\ ${ }^{6}$ Biogeochemistry and Multiphase Chemistry Departments, Max Planck Institute for Chemistry, Mainz, Germany \\ ${ }^{7}$ Applied Physics Department \& Atmospheric Science Department, University of São Paulo, São Paulo, Brazil \\ *now at: State Key Joint Laboratory of Environmental Simulation and Pollution Control, College of Environmental Sciences \\ and Engineering, Peking University, Beijing, China \\ *** now at: Department of Chemistry, Colorado State University, Fort Collins, CO, USA \\ *** now at: Earth Observatory of Singapore, Nanyang Technological University, Singapore \\ ***** now at: Institute of Meteorology and Geophysics, University of Innsbruck, Austria \\ ${ }^{* * * * * *}$ now at: Atmospheric Sciences and Global Change Division, Pacific Northwest National Laboratory, Richland, WA, USA
}

Correspondence to: S. T. Martin (scot_martin@harvard.edu) and P. Artaxo (artaxo@if.usp.br)

Received: 2 May 2014 - Published in Atmos. Chem. Phys. Discuss.: 19 June 2014

Revised: 11 March 2015 - Accepted: 15 March 2015 - Published: 2 April 2015

\begin{abstract}
Real-time mass spectra of the non-refractory species in submicron aerosol particles were recorded in a tropical rainforest in the central Amazon Basin during the wet season from February to March 2008, as a part of the Amazonian Aerosol Characterization Experiment (AMAZE08). Organic material accounted on average for more than $80 \%$ of the non-refractory submicron particle mass concentrations during the period of measurements. There was insufficient ammonium to neutralize sulfate. In this acidic, isoprene-rich, $\mathrm{HO}_{2}$-dominant environment, positive-matrix factorization of the time series of particle mass spectra identified four statistical factors to account for the $99 \%$ of the variance in the signal intensities of the organic constituents. The first factor was identified as associated with regional and local pollution and labeled "HOA" for its hydrocarbon-like characteristics. A second factor was associated with longrange transport and labeled "OOA-1" for its oxygenated
\end{abstract}

characteristics. A third factor, labeled "OOA-2," was implicated as associated with the reactive uptake of isoprene oxidation products, especially of epoxydiols to acidic haze, fog, or cloud droplets. A fourth factor, labeled "OOA-3," was consistent with an association with the fresh production of secondary organic material (SOM) by the mechanism of gasphase oxidation of biogenic volatile organic precursors followed by gas-to-particle conversion of the oxidation products. The suffixes 1,2, and 3 on the OOA labels signify ordinal ranking with respect to the extent of oxidation represented by the factor. The process of aqueous-phase oxidation of water-soluble products of gas-phase photochemistry might also have been associated to some extent with the OOA-2 factor. The campaign-average factor loadings had a ratio of $1.4: 1$ for OOA-2:OOA-3, suggesting the comparable importance of particle-phase compared to gas-phase pathways for the production of SOM during the study period. 


\section{Introduction}

Aerosol particles in the atmosphere make an important contribution to the Earth's radiation budget (IPCC, 2013). They can directly scatter and absorb shortwave and longwave radiation, and they can indirectly affect radiative forcing and precipitation by modifying cloud properties. The assessment of the impact of human perturbations on climate requires an understanding of the natural functioning of the aerosolcloud-climate system. During the wet season, the pristine Amazon Basin provides a unique environment for studying the sources and atmospheric evolution of natural aerosol particles and hence for understanding the role of aerosol particles in biosphere-atmosphere interactions (Andreae, 2007; Martin et al., 2010a).

Tropical forest emissions and long-range transport from outside of the basin are major contributors to the number and mass budgets of Amazonian aerosol particles during the wet season because regional biomass burning emission is largely suppressed by heavy rainfall (Martin et al., 2010a). The forest ecosystem emits biogenic volatile organic compounds (BVOCs) that can be oxidized in the atmosphere, principally by reaction with photochemically produced hydroxyl radical and ozone molecules. Some of the oxidized products have sufficiently low vapor pressures to condense and produce secondary organic material (SOM) in the particle phase. Moreover, in haze, fog, and cloud droplets, the production of organic acids and oligomers can occur from the $\mathrm{OH}$-initiated aqueous-phase oxidation of the photooxidation products of isoprene, e.g., glyoxal, methacrolein (MACR), and methyl vinyl ketone (MVK) (Lim et al., 2010), as well as from the acid-catalyzed reactive uptake of epoxydiol isomers (IEPOXs) (Surratt et al., 2010; Lin et al., 2012). For SOM produced by these aqueous-phase pathways, a fraction of the mass can remain in the particle phase after dehumidification. In addition, the forest also directly emits primary biological particles containing potassium, phosphorus, sugars, sugar alcohols, and fatty acids, including an upper limit of a $20 \%$ contribution to the submicron organic-mass concentration (Graham et al., 2003a; Elbert et al., 2007; Schneider et al., 2011; Pöhlker et al., 2012). The forest also emits gases important to the particle mass concentrations of inorganic ions. For example, ammonia partitions from the gas phase to acidic particles (Trebs et al., 2005). Reduced sulfur gases undergo atmospheric oxidation to produces sulfuric acid that condenses to the particle phase (Andreae et al., 1990).

The Amazonian Aerosol Characterization Experiment 2008 (AMAZE-08) investigated the sources and properties of Amazonian particles (Martin et al., 2010b). Evidence from AMAZE-08 led to the conclusion that there is a large-scale contribution of biogenic SOM to the mass concentration of submicron aerosol particles during the wet season (Chen et al., 2009; Martin et al., 2010b; Pöschl et al., 2010; Schneider et al., 2011). In particular, Chen et al. (2009) demonstrated that on the order of $90 \%$ of the organic material of submi- cron Amazonian particles arises from the in-basin production of biogenic SOM. Primary biogenic particles enriched in potassium salts and emitted by fungal spores as $10-20 \mathrm{~nm}$ dried particles possibly provide surfaces for the condensation of SOM from the gas phase (Pöhlker et al., 2012). These bio-related particles participate in the regulation of the hydrological cycle of the forest by serving as nuclei for cloud formation and subsequent precipitation (Gunthe et al., 2009; Prenni et al., 2009). In addition to particle production tied to the forest ecosystem, lidar and satellite observations provide evidence of episodic long-range advection of African smoke and Saharan dust (Ben-Ami et al., 2010; Baars et al., 2011). These intrusions are temporally consistent with increases in heavily oxidized organic particles observed by Chen et al. (2009), indicative of long atmospheric residence times, as well as increases in the concentrations of ice nuclei observed by Prenni et al. (2009).

The present study analyzes multiple data sets collected during AMAZE-08 in relation to one another and in the context of the chemistry and properties of submicron particles in the Amazon Basin during the wet season. Our topic of focus is the relative importance to the production of SOM mass concentration of aqueous-phase reactions compared to gas-phase oxidation followed by condensation. The relative importance of these two pathways remains poorly understood (Martin et al., 2010a; Ervens et al., 2011). On the one hand, condensational growth has been reported as an important pathway of the biogenic SOM production (Graham et al., 2003a). On the other hand, a significant role of liquid-phase processing for Amazonian aerosol particles is proposed (Pöhlker et al., 2012). In the current study, positivematrix factorization of the time series of particle mass spectra is used to identify statistical factors that differ in mass spectral patterns (Zhang et al., 2011). The properties of these factors, in conjunction with the auxiliary data sets, are used to investigate the relative importance of different possible sources of submicron organic material in Amazonia during the wet season.

\section{Site and instrument description}

Ground-based measurements were carried out at a rainforest site during the wet season from 7 February to 13 March 2008 (Martin et al., 2010b). The site $\left(02^{\circ} 35.68^{\prime} \mathrm{S}, 60^{\circ} 12.56^{\prime} \mathrm{W}\right.$, $110 \mathrm{~m}$ above sea level) is located $60 \mathrm{~km}$ NNW of Manaus and faces $1600 \mathrm{~km}^{2}$ of nearly pristine forest to the east to the Atlantic Ocean. The site was accessed by a $34 \mathrm{~km}$ unpaved road from Highway 174 (Fig. S1 in the Supplement). The 10-day back trajectories indicated that during the measurement period the air masses mainly originated from the northeast over the Atlantic Ocean in the direction of Cape Verde and the Canary Islands. Air was sampled at the top of a tower ("TT34"; $38.75 \mathrm{~m}$ ) above the forest canopy (33 m). 
Instrumentation deployed during AMAZE-08 is described in Martin et al. (2010b).

The present study focuses mostly on the statistical analysis of the data sets of an Aerodyne high-resolution aerosol mass spectrometer (HR-AMS) in the context of complementary data sets of other instruments. Mass concentrations were adjusted to standard temperature and pressure (noted as STP; $273.15 \mathrm{~K}$ and $10^{5} \mathrm{~Pa}$ ), which were approximately $10 \%$ greater than those at calibration conditions $(299.3 \mathrm{~K}$ and $100591.7 \mathrm{~Pa}$ ). Details on sampling by the AMS and data analysis are provided in Chen et al. (2009) and Sect. S1 in the Supplement. The description of other concurrent measurements and the comparisons among the measurements are provided in Sect. S2. Table S1 in the Supplement lists the regression coefficients for the multi-instrument data comparison. For a collection efficiency of unity, the AMS data agreed within measurement uncertainty with the other data sets, which is consistent with the understanding that liquid particles do not bounce from the AMS vaporizer (Matthew et al., 2008). Images of filter samples showed that spherical organic particles, appearing as liquid-like droplets, were the main population in the submicron fraction of the ambient particle population for AMAZE-08 (Pöschl et al., 2010).

Atomic ratios of oxygen to carbon $(\mathrm{O}: \mathrm{C})$, hydrogen to carbon $(\mathrm{H}: \mathrm{C})$, nitrogen to carbon $(\mathrm{N}: \mathrm{C})$, and sulfur to carbon $(\mathrm{S}: \mathrm{C})$, as well as the organic-mass-to-organic-carbon (OM : OC) ratios, were calculated from the high-resolution "W-mode" data (Aiken et al., 2008). The ratios were corrected by the method of Canagaratna et al. (2015). The contributions of organonitrates and organosulfates, detected as inorganic nitrate or sulfate ions by the AMS, to the elemental ratios were negligible because of their low mass concentrations (see Sect. S1). Positive-matrix factorization (PMF) (Paatero and Tapper, 1994) was conducted on the organicmass spectra of the medium-resolution "V-mode" data $(\mathrm{m} / \mathrm{z}$ 12-220) taken to unit-mass resolution. The analysis used the PMF evaluation panel of Ulbrich et al. (2009) (version 4.2; "robust mode"). Further aspects of the analysis and output evaluation are provided in Sect. S3. Because of the low mass concentrations, the signal-to-noise ratios were insufficient for satisfactory PMF analysis of the high-resolution data. PMF results are reported herein for unit-mass resolution.

The AMS mass spectra of SOM produced in the Harvard Environmental Chamber (HEC) by (i) the photooxidation of isoprene $\left(\mathrm{C}_{5} \mathrm{H}_{8}\right)$, (ii) the dark ozonolysis of the monoterpene $\alpha$-pinene $\left(\mathrm{C}_{10} \mathrm{H}_{16}\right)$ (adapted from Shilling et al., 2009), and (iii) the dark ozonolysis of the sesquiterpene $\beta$-caryophyllene $\left(\mathrm{C}_{15} \mathrm{H}_{24}\right)$ are reported herein for the purpose of comparison to the AMAZE-08 data. Experimental details are described elsewhere (Shilling et al., 2009; King et al., 2010; Chen et al., 2011, 2012). A library of spectra was collected at different SOM mass concentrations.

\section{Results and discussion}

\subsection{Mass concentrations}

Figure 1 shows a time series of measurements by the AMS and other instruments during AMAZE-08. The AMS detects the non-refractory chemical components of the submicron fraction of the ambient particle population (NR$\mathrm{PM}_{1}$ ) (Fig. 1a-c). As described in Chen et al. (2009), organic material and sulfate were the two major components identified by the AMS, with correspondingly low concentrations of ammonium and negligible concentrations of nitrate and chloride. The campaign-average organic-particle mass concentration was $0.76 \pm 0.23 \mu \mathrm{g} \mathrm{m}^{-3}$, corresponding to $0.45 \pm 0.13 \mu \mathrm{g} \mathrm{C} \mathrm{m}^{-3}$ of organic carbon and an $\mathrm{OM}: \mathrm{OC}$ ratio of 1.7 . The campaign-average sulfate mass concentration of $0.19 \pm 0.06 \mu \mathrm{g} \mathrm{m}^{-3}$ agreed well with the average value of $0.21 \pm 0.06 \mu \mathrm{g} \mathrm{m}^{-3}$ measured by ion chromatography (IC) and the value of $0.24 \pm 0.05 \mu \mathrm{g} \mathrm{m}^{-3}$ measured by particle-induced X-ray emission (PIXE) for the fine-mode $\left(\mathrm{PM}_{2}\right)$ filters. Ammonium accounted for $2 \%$ of the submicron particle mass concentration. The campaign-average mass concentration was $0.03 \pm 0.01 \mu \mathrm{g} \mathrm{m}^{-3}$, in agreement with the average value of $0.04 \pm 0.01 \mu \mathrm{g} \mathrm{m}^{-3}$ obtained for the fine-mode filters by the IC analysis. Chloride concentrations had a campaign-average concentration of $2 \mathrm{ng} \mathrm{m}^{-3}$, which was consistent with the filter average, though there were transiently higher levels (up to $26 \mathrm{ng} \mathrm{m}^{-3}$ ) during some periods. Nitrate had a campaign-average concentration of $7 \pm 2 \mathrm{ng} \mathrm{m}^{-3}$. This value was greater than the average finemode concentration of $4 \pm 1 \mathrm{ng} \mathrm{m}^{-3}$ measured by IC, perhaps because of increased instrument uncertainties at low concentrations. Another possibility, meaning substantial evaporative losses of nitrate during filter sampling, is not anticipated for the hygroscopic, acidic particles present during the measurement periods for the prevailing relative humidity. The AMSmeasured nitrate accounted for $0.6 \%$ of the total submicron particle mass concentration.

Black carbon, mineral dust, and sea salt are common refractory components that are not quantified by the AMS. The multiangle absorption photometer (MAAP) instrument provides an optically based measurement of the black-carbonequivalent (BCe) mass concentration, without size resolution (Petzold et al., 2002). The campaign-average concentration was $0.13 \mu \mathrm{g} \mathrm{m}^{-3}$ (Fig. 1d). Under a limiting assumption that all black carbon occurred in the submicron fraction of the atmospheric particle population, this concentration corresponded to $11 \%$ of the submicron mass concentration (inset of Fig. 1e). The relative contribution of black carbon varied significantly during the course of AMAZE-08 (Fig. 1e), perhaps corresponding to the occasional advection of urban pollution from Manaus or biomass burning from Africa (Kuhn et al., 2010; Martin et al., 2010b; Rizzo et al., 2013). This interpretation is supported by the covariance of BCe with sulfate. Major fine-mode $\left(\mathrm{PM}_{2}\right)$ trace elements of mineral dust, in- 


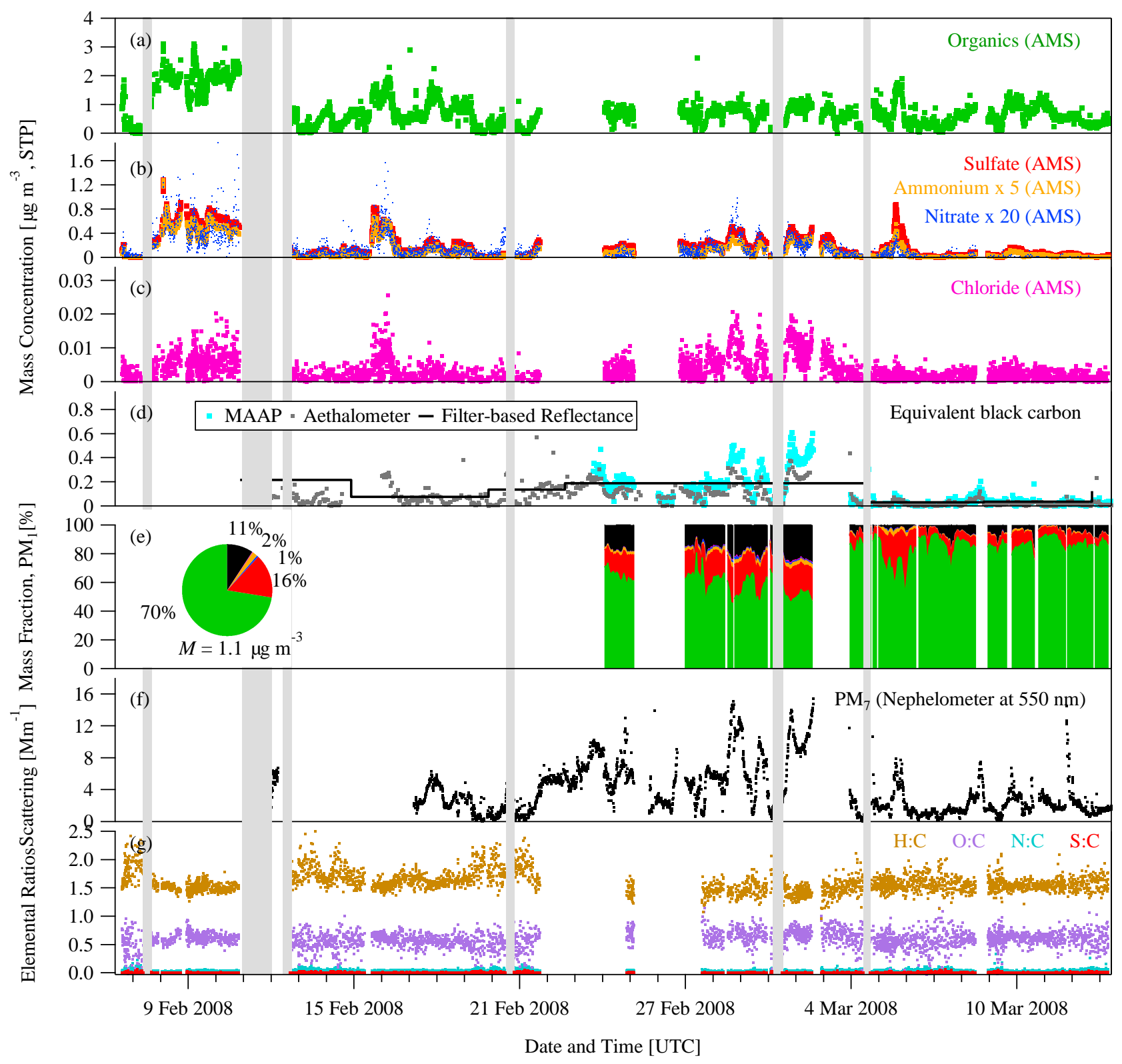

Figure 1. Time series of observations during AMAZE-08. (a, b, c) Organic, sulfate, ammonium, nitrate, and chloride mass concentrations measured by AMS. (d) Black-carbon-equivalent mass concentrations measured by filter-based reflectance (fine-mode) analysis as well as optically derived by MAAP $(637 \mathrm{~nm})$ and aethalometer $(660 \mathrm{~nm})$ measurements. (e) Component mass fractions of (a-d). For (d), MAAP data were used. The inset pie chart represents the campaign average. (f) Scattering coefficient measured by nephelometry at $550 \mathrm{~nm}$. Only particles of $7 \mu \mathrm{m}$ and smaller passed through the sampling inlet. (g) Elemental ratios $\mathrm{O}: \mathrm{C}, \mathrm{H}: \mathrm{C}, \mathrm{N}: \mathrm{C}$, and $\mathrm{S}: \mathrm{C}$ for the submicron organic particles, as determined by high-resolution AMS data. Except for (f), the data represent the submicron or fine-mode fraction of the ambient particle population. Concentrations are normalized to STP conditions (see main text). Periods in gray were influenced by local generator exhaust plume during times of local wind reversal and were excluded from the shown data sets and analysis.

cluding $\mathrm{Si}, \mathrm{Al}, \mathrm{Fe}$, and $\mathrm{Ca}$, had campaign-average mass concentrations of $0.12,0.05,0.04$, and $0.01 \mu \mathrm{g} \mathrm{m}^{-3}$, respectively, as analyzed for fine-mode filter samples by PIXE. An important source of the mineral dust was long-range transport from Africa. Previous campaigns in the Amazon found that about $20 \%$ of the mineral dust occurred in the submicron domain (Fuzzi et al., 2007). Using this result for AMAZE-08 implies that mineral dust contributed about $0.1 \mu \mathrm{g} \mathrm{m}^{-3}$ to the average mass concentration of the submicron particle population (Malm et al., 1994). The modified pie chart is shown in Fig. S2. Moreover, the campaign-average mass concentrations of fine-mode metallic elements $(\mathrm{V}, \mathrm{Cr}, \mathrm{Mn}, \mathrm{Ni}, \mathrm{Cu}$, 
$\mathrm{Zn}, \mathrm{Pb}$, and $\mathrm{Mg}$, with a total of $2 \mathrm{ng} \mathrm{m}^{-3}$ ) measured by PIXE were sufficiently low during AMAZE-08 to confirm the absence in the submicron particle mass concentration of significant metals from anthropogenic sources. The campaignaverage mass concentration of fine-mode $\mathrm{Na}^{+}$measured by IC was $0.02 \mu \mathrm{g} \mathrm{m}^{-3}$. This result suggests a minimal contribution of sea salt from the Atlantic Ocean, at least to the submicron particle population (Fuzzi et al., 2007).

Figure if shows the time series of the particle lightscattering coefficient measured by nephelometry at $550 \mathrm{~nm}$ for $\mathrm{PM}_{7}$. The elevated scattering coefficients during 22 February-3 March 2008 were driven by elevated mineral dust concentrations in the coarse mode, along with elevated submicron sulfate, $\mathrm{BCe}$, and organic material arising from the advection of the Manaus pollution plume as well as long-range transport from Africa (Sect. S2). Other temporal maxima corresponded to increases in submicron particle mass concentration. Figure $1 \mathrm{~g}$ shows the elemental compositions of the submicron organic material measured by the AMS. The $\mathrm{O}: \mathrm{C}$ and $\mathrm{H}: \mathrm{C}$ ratios, corrected as described in Canagaratna et al. (2015), were $0.58 \pm 0.16$ (1 SD) and $1.60 \pm 0.18$, on average, respectively. The $10 / 90$ quantiles were $0.40 / 0.74$ and $1.42 / 1.80$, respectively. The $\mathrm{N}: \mathrm{C}$ ratios were $0.03 \pm 0.01$.

Ammonium and sulfate mass concentrations had a high correlation $\left(R^{2}=0.95\right)$ during AMAZE-08 (Fig. S3). The molar ratio of $\mathrm{NH}_{4}^{+}: \mathrm{SO}_{4}^{2-}$ was 0.80 (Fig. 2), meaning that there was insufficient ammonium to neutralize sulfate for the submicron particle population and suggesting a composition close to that of ammonium bisulfate. Similar molar ratios have been reported in several previous studies in the central and northeast Amazon Basin (Talbot et al., 1988, 1990; Gerab et al., 1998; Graham et al., 2003b). The AMS is unable to quantify refractory components such as $\mathrm{K}^{+}, \mathrm{Na}^{+}, \mathrm{Ca}^{2+}$, and $\mathrm{Mg}^{2+}$. Mass-diameter distributions of these ions obtained by IC analysis of samples collected by a multi-orifice uniform deposit impactor (MOUDI) on 22 March 2008 suggest that $40 \%$ of the mass of these ions was distributed to the submicron particle fraction. For comparison, Fuzzi et al. (2007) for the wet season reported 50$60 \%$ of $\mathrm{K}^{+}$and $\mathrm{Ca}^{2+}$ in the submicron fraction, compared to the predominance of $\mathrm{Na}^{+}$and $\mathrm{Mg}^{2+}$ in the supermicron fraction. The campaign-average fine-mode mass concentrations of $\mathrm{K}^{+}, \mathrm{Ca}^{2+}, \mathrm{Na}^{+}$, and $\mathrm{Mg}^{2+}$ measured by IC were $0.03,0.01,0.02$, and $0.01 \mu \mathrm{g} \mathrm{m}^{-3}$, respectively. The implication of the relative concentrations (i.e., sulfate concentration of $0.19 \pm 0.06 \mu \mathrm{g} \mathrm{m}^{-3}$ ) is that the submicron inorganic ion composition is reasonably approximated as ammonium bisulfate during AMAZE-08.

Diel profiles of organic, sulfate, ammonium, nitrate, and chloride mass concentrations measured by the AMS are shown in Fig. 3. The temporal trends of the four species were correlated, with a minimum in mass concentrations near daybreak and a maximum in the afternoon. Nighttime rainfall efficiently removed particle mass concentration after local midnight, suggesting an absence of strong sources of submicron particles during the night. From the morning to the afternoon, photochemical production of SOM, convective mixing of particles from aloft, and regional advection sustained mass concentrations, with quick recovery after daytime rainfall. Precipitation was typically local, whereas advection was typically regional on a larger scale than precipitation. The decrease and the recovery of species concentration during the afternoon resulted from frequent rain events around that time of day (e.g., Fig. S4). The organic-particle mass concentration increased during the day even as temperature rose and relative humidity dropped, both of which provide a thermodynamic driving force for the repartitioning of semivolatile species from the particle phase to the gas phase (Pankow, 1994). Possible explanations include (1) sufficiently strong daytime production of SOM to outweigh evaporative sinks, (2) significant production of low-volatility SOM (Ervens et al., 2011; Ehn et al., 2014), or (3) a slow evaporation rate of SOM (Vaden et al., 2011).

\subsection{Mass spectra of laboratory biogenic SOM}

As a reference for interpreting the AMAZE-08 measurements, Fig. 4 shows the mass spectra of SOM produced in the HEC by the oxidation of isoprene, $\alpha$-pinene, and $\beta$ caryophyllene for three different mass concentrations. Signals at $m / z<60$ account for 93-97, 80-84, and 71-79\% of the total signal intensity for the three types of SOM. The fragmentation pattern extends to higher $\mathrm{m} / \mathrm{z}$ for the increasing carbon skeleton of precursor BVOC. For all three types of SOM, the relative intensities of two prominent ions, $\mathrm{C}_{2} \mathrm{H}_{3} \mathrm{O}^{+}$ at $m / z 43$ and $\mathrm{CO}_{2}^{+}$at $m / z 44$, show opposite trends as the mass concentration increases. The former increases for elevated concentrations, whereas the latter decreases. Another ion at $m / z 44, \mathrm{C}_{2} \mathrm{H}_{4} \mathrm{O}^{+}$, shows a trend similar to that of $\mathrm{C}_{2} \mathrm{H}_{3} \mathrm{O}^{+}$. This ion accounts for $10-25,3-5$, and $5-10 \%$ of the signal at $m / z 44$ for the isoprene, $\alpha$-pinene, and $\beta$ caryophyllene SOMs, respectively. The relative intensities of major $\mathrm{C}_{\mathrm{x}} \mathrm{H}_{\mathrm{y}}^{+}$ions, such as $\mathrm{CH}_{3}^{+}$at $m / z 15, \mathrm{C}_{2} \mathrm{H}_{3}^{+}$at $m / z 27$, $\mathrm{C}_{3} \mathrm{H}_{3}^{+}$at $m / z 39$, and $\mathrm{C}_{3} \mathrm{H}_{5}^{+}$at $m / z 41$, typically increase as concentration increases. The most intense $\mathrm{C}_{\mathrm{x}} \mathrm{H}_{\mathrm{y}}^{+}$ions at $m / z>80$ for the three types of biogenic SOM is $\mathrm{C}_{7} \mathrm{H}_{7}^{+}$at $m / z$ 91, which does not occur in the spectra for fresh emissions such as diesel exhaust, cooking, and biomass burning but is similar to the spectra for aged primary emissions (Chirico et al., 2010; He et al., 2010; Ortega et al., 2013).

Compared to the spectra of the other types of biogenic $\mathrm{SOM}$, isoprene-derived $\mathrm{SOM}$ under $\mathrm{HO}_{2}$-dominant conditions has a unique signature. " $\mathrm{HO}_{2}$-dominant" refers to the fate of peroxy radicals with respect to reaction with $\mathrm{HO}_{2}$ or NO. The relative intensities of $\mathrm{CHO}^{+}$at $m / z 29, \mathrm{CH}_{2} \mathrm{O}^{+}$ at $m / z 30, \mathrm{CH}_{3} \mathrm{O}^{+}$at $m / z 31, \mathrm{C}_{3} \mathrm{H}_{6} \mathrm{O}_{2}^{+}$at $m / z 74$, and $\mathrm{C}_{3} \mathrm{H}_{7} \mathrm{O}_{2}^{+}$at $m / z 75$ in the spectra of isoprene-derived SOM are much greater, and the contributions of $\mathrm{C}_{\mathrm{x}} \mathrm{H}_{\mathrm{y}}^{+}$ions are 


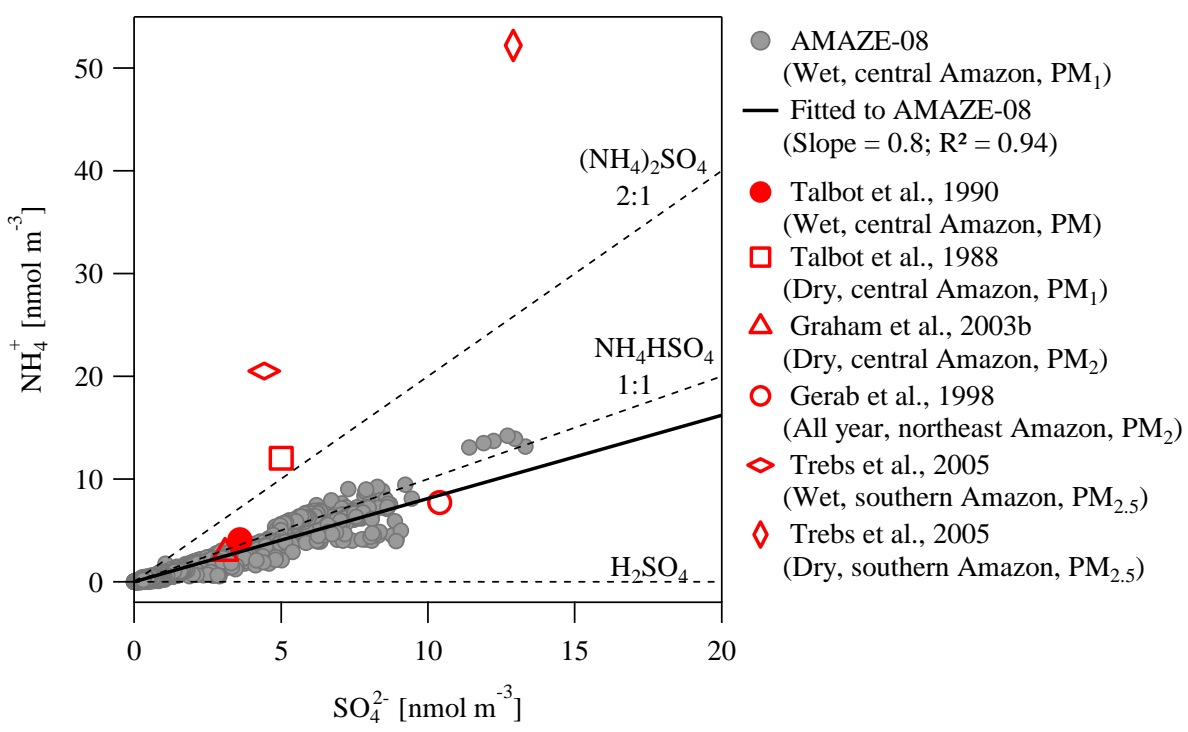

Figure 2. Scatterplot of ammonium and sulfate mass concentrations (gray circles). The red symbols show campaign-average values reported in the literature for other measurements in the Amazon Basin, both in the wet and dry seasons.

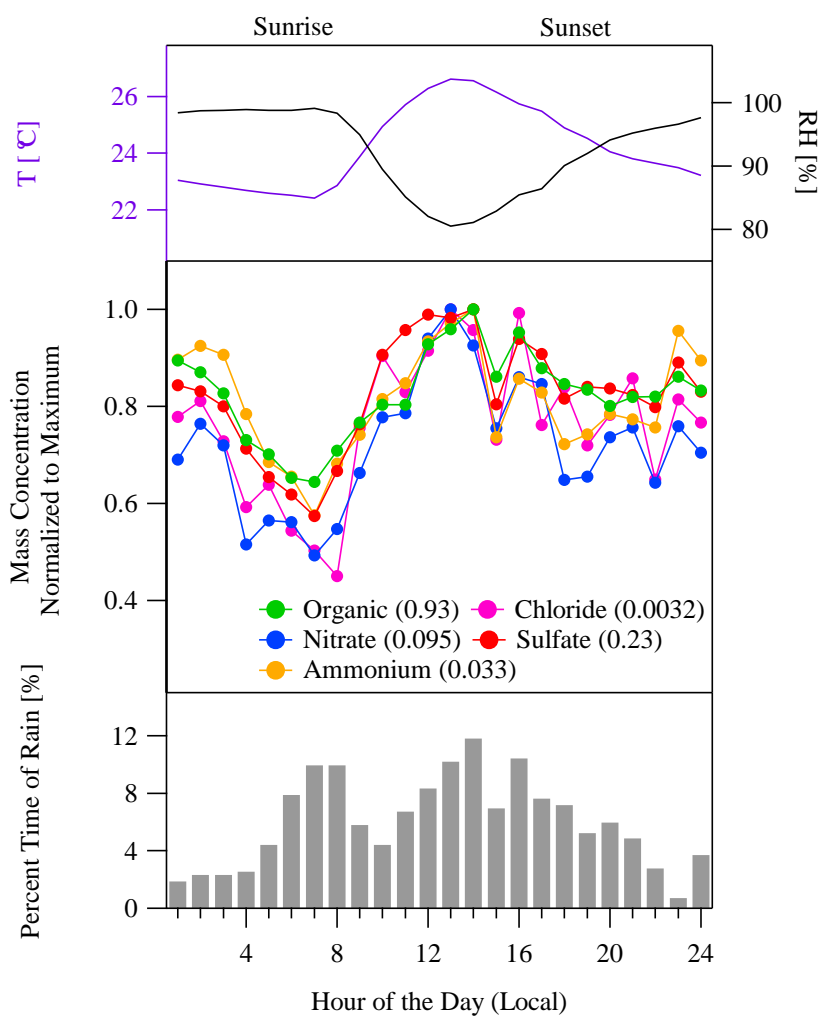

Figure 3. Diel profiles of (top) the temperature and relative humidity at the top of the measurement tower, (middle) normalized AMSmeasured speciated mass concentrations (maximum concentrations in $\mu \mathrm{g} \mathrm{m}^{-3}$ (STP) are shown in parentheses), and (bottom) percent occurrence of rain. Data represent mean values. less, especially for $m / z>65$. Moreover, $m / z 82$ that mainly consists of $\mathrm{C}_{3} \mathrm{H}_{5} \mathrm{O}^{+}$appears to be the most intense peak for $m / z \geq 75$. This fragment has been suggested as a characteristic fragment of isoprene-derived SOM (Robinson et al., 2011). Isoprene-derived SOM also does not follow the empirical linear relationship between $\mathrm{O}: \mathrm{C}$ and $I_{44}: I_{\text {org }}$ described by Aiken et al. (2008) (Fig. S5), indicating that deriving O : C from $I_{44}: I_{\text {org }}$ requires careful judgments on the contribution of isoprene-derived SOM.

\subsection{Multivariate factor analysis of the organic-mass spectra}

Multivariate analysis by PMF of the temporal series of the organic component of the mass spectra was carried out for $12 \leq m / z \leq 220$ at unit-mass resolution. In overview, four statistical factors were identified and labeled as HOA, OOA1, OOA-2, and OOA-3 (Fig. 5). These four factors respectively accounted for $2,18,14$, and $66 \%$ of the variance in the data matrix, with a residual variance of $<1 \%$. The time series of the loading of each statistical factor are shown in Fig. 6. By definition, the mass spectrum of the organic chemical component itself was at any time point a linear mix of the statistical factors plus residual.

The HOA factor (Fig. 5a) was dominated by the ion series $\mathrm{C}_{n} \mathrm{H}_{2 n+1}^{+}, \mathrm{C}_{n} \mathrm{H}_{2 n-1}^{+}$, and $\mathrm{C}_{n} \mathrm{H}_{2 n-3}^{+}(m / z 27,29,39,41,43$, $55,57,67,69, \ldots)$, similar to that reported for other locations (e.g., Zhang et al., 2005; Docherty et al., 2011; Robinson et al., 2011) and to that observed for engine exhaust (Canagaratna et al., 2004; Chirico et al., 2010). This statistical factor is typically taken as an organic component associated with fossil fuel combustion emissions that have not undergone substantial atmospheric oxidation. This factor was 


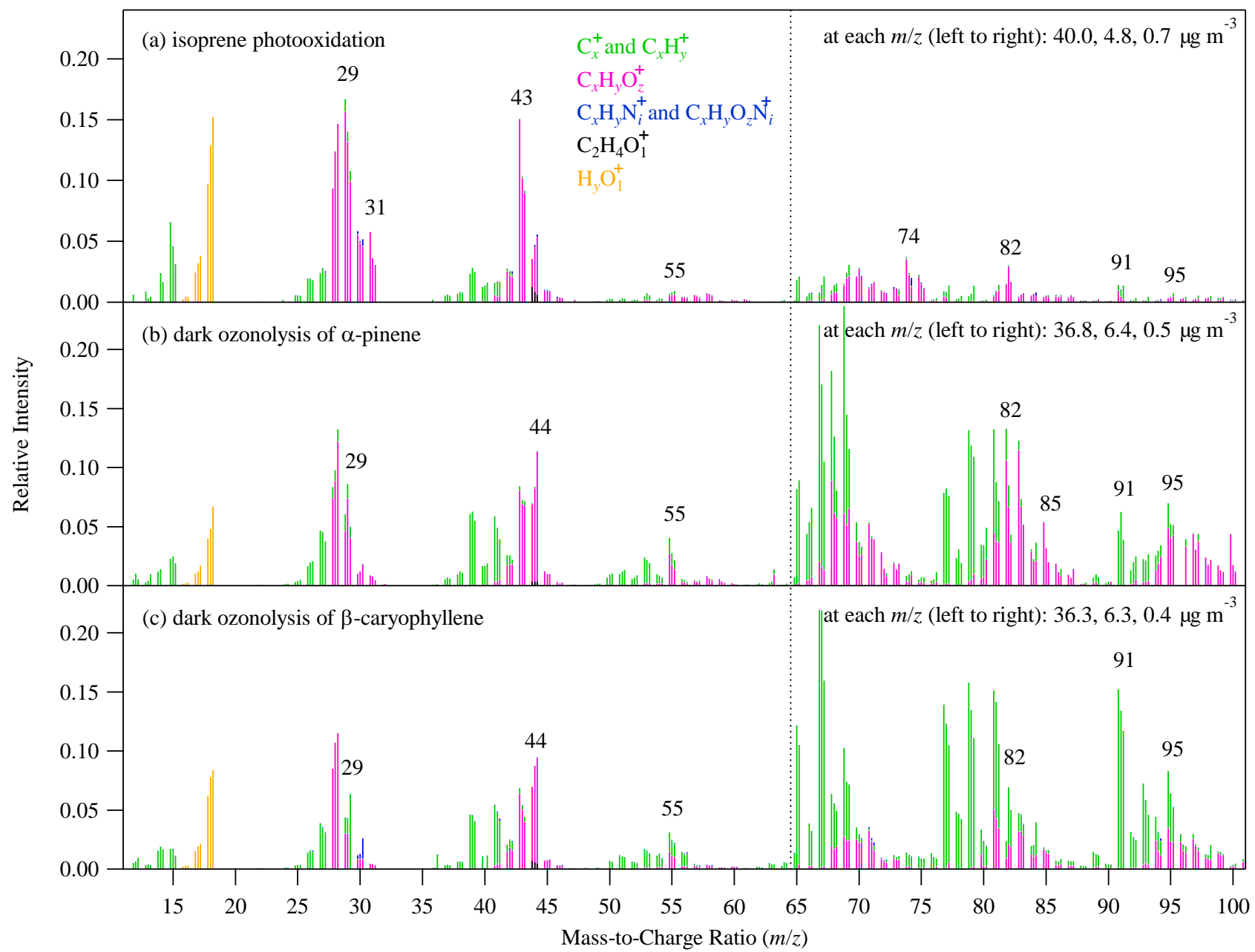

Figure 4. High-resolution mass spectra of secondary organic material produced in the Harvard Environmental Chamber by the oxidation of isoprene, $\alpha$-pinene, and $\beta$-caryophyllene. The $\mathrm{NO}_{\mathrm{x}}$ concentration was measured as $<1 \mathrm{ppbv}$ during these experiments and was estimated later as $<70 \mathrm{ppt}$ for typical operating of the HEC (Liu et al., 2013). The relative intensities of ions having $m / z \geq 65$ were multiplied by 10. The intensities at each $\mathrm{m} / z$ represent three experiments that were performed at different SOM particle mass concentrations. A single intensity bar is color-coded by the contribution of different ion families (i.e., fragments containing $\mathrm{C}, \mathrm{H}, \mathrm{O}$, or $\mathrm{N}$ for subscripts of $\mathrm{x}$, y, $\mathrm{z}$, $i \geq 1$ ) as determined from the analysis of the high-resolution spectra (Shilling et al., 2009). The relative intensities of the $\mathrm{H}_{\mathrm{y}} \mathrm{O}_{1}^{+}$family were derived from the intensity of $\mathrm{CO}_{2}^{+}$based on calibrations described in Chen et al. (2011).

especially prevalent in the early part of the experiment. During this time period, other pollution tracers such as sulfate and $\mathrm{NO}_{\mathrm{x}}$ were also at elevated concentrations. Regional pollution from Manaus and local emissions (e.g., nearby roads, highway, generator, and pump oil) were plausible contributors to the loading of the HOA factor (Ahlm et al., 2009; Rizzo et al., 2013).

The factors OOA-1, OOA-2, and OOA-3 were ranked by the $f_{44}: f_{43}$ ratios (high to low) and labeled based on Zhang et al. (2011), where $f_{m / z}$ represents the fractional contribution of the signal intensity at $m / z$ to the statistical factor. The signal intensity was dominated at $m / z 44$ by the $\mathrm{CO}_{2}^{+}$fragment and at $m / z 43$ by the $\mathrm{C}_{2} \mathrm{H}_{3} \mathrm{O}^{+}$and $\mathrm{C}_{3} \mathrm{H}_{7}^{+}$fragments. The $f_{44}: f_{43}$ ratio has been used in some settings as a surro- gate for the extent of oxidation (i.e., so-called "atmospheric aging") of SOM (Ng et al., 2010, 2011).

The OOA-1 factor had the feature of a singularly dominant peak at $m / z 44$ (Fig. 5b).This marker has been linked to organic material that has undergone extensive oxidation during a prolonged atmospheric residence time (on the order of 10 days) (Ng et al., 2010; Lambe et al., 2011). This factor is consistent with finding of highly oxidized organic material delivered by long-range transport, as occurred during some periods of AMAZE-08 (Chen et al., 2009). The source of this material was plausibly African biomass burning, as supported by concurrent lidar measurements (Baars et al., 2011) and satellite observations (Ben-Ami et al., 2010). Biomass burning in South America was much less signifi- 


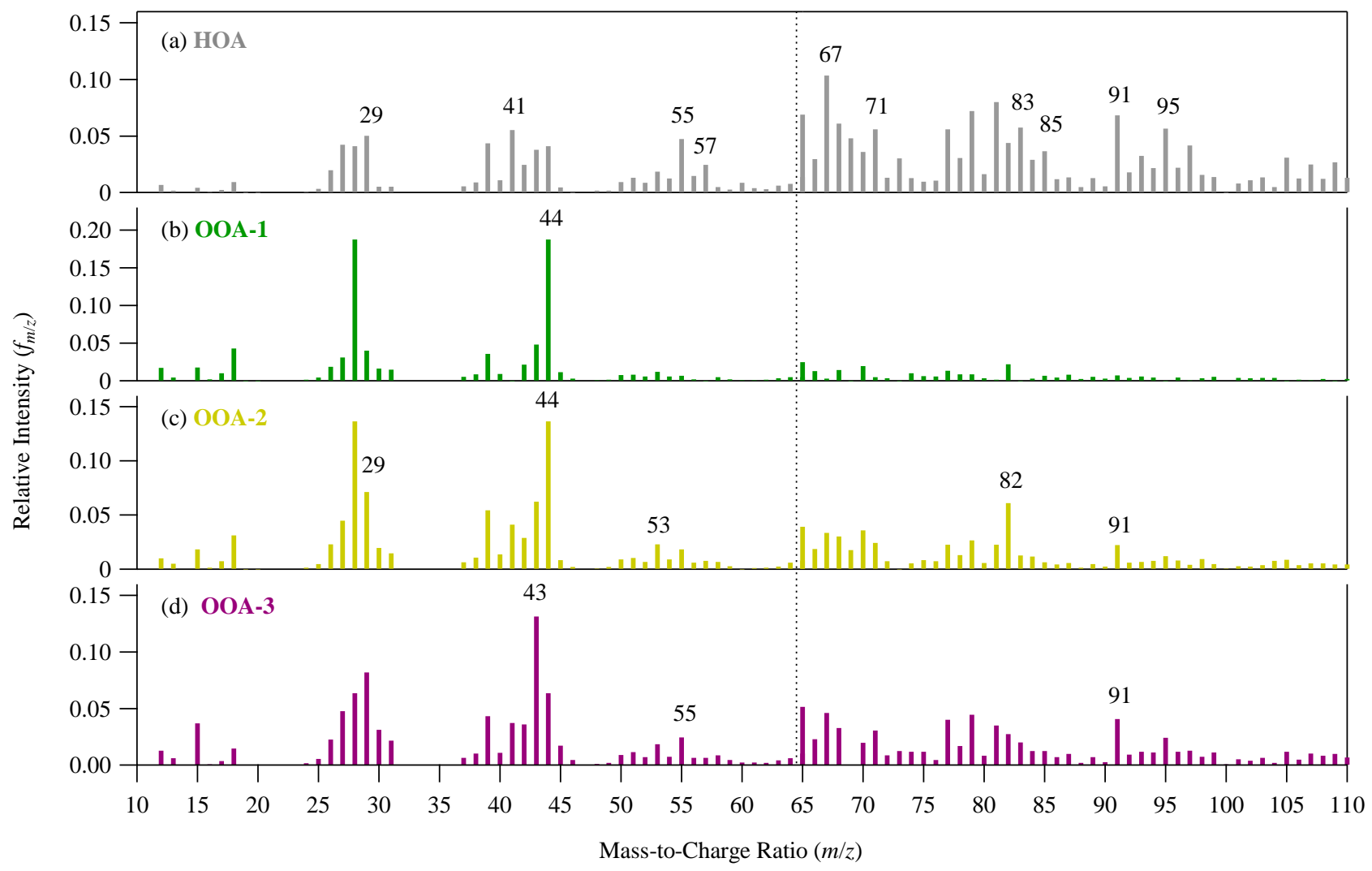

Figure 5. Statistical factors HOA, OOA-1, OOA-2, and OOA-3 identified by PMF analysis. The relative intensities of ions having $m / z \geq 65$ were multiplied by 10 .

cant during the wet season (Martin et al., 2010b). The correlations of the statistical loadings of the OOA-1 factor with the measured mass concentrations of biomass burning tracers, such as chloride $\left(R^{2}=0.52\right)$, potassium $\left(R^{2}=0.35\right)$, and black carbon $\left(R^{2}=0.43\right)$ in the submicron particle population, were not high, possibly because of the mixing of sources with these tracers such as primary biological particles (i.e., contributing chloride and potassium) and regional pollution from Manaus to (i.e., black carbon). These correlation values were, however, significantly greater than those of the other three factors (HOA, OOA2, and OOA-3) with the tracers (i.e., $R^{2}<0.10$ for chloride, $R^{2}<0.02$ for potassium, and $R^{2}<0.20$ for black carbon) (Fig. 6b). Elevated sulfate mass concentrations were also observed during periods having high OOA-1 loadings (Fig. 1b).

Features of the OOA-2 factor included (1) a $f_{44}: f_{43}$ ratio greater than unity and (2) a characteristic peak at $m / z$, mainly consisting of $\mathrm{C}_{3} \mathrm{H}_{5} \mathrm{O}^{+}$. This peak was the most abundant for $m / z \geq 75$ (Fig. 5c). It is similar to that reported for PMF factors identified in the tropical rainforest of Borneo (called the "82Fac" factor; Robinson et al., 2011), the rural area of southwest Ontario, Canada (called the "UNKN" factor; Slowik et al., 2011), and isoprene-rich downtown Atlanta, Georgia, USA (called the "IEPOX-OA" factor; Bud- isulistiorini et al., 2013). Robinson et al. (2011) concluded that this factor derived from SOM produced by isoprene photooxidation. In agreement with this, the time series of OOA-2 loading correlated with isoprene concentration $\left(R^{2}=0.65\right)$ as well as with the sum concentration of first-generation isoprene oxidation products, specifically MVK $+\operatorname{MACR}\left(R^{2}=\right.$ 0.74 ) (Fig. 6c). The characteristic $m / z 82$ also occurred in the spectra of our isoprene SOM produced in the presence of neutral sulfate particles at $40 \%$ relative humidity (RH) (Fig. 4a). Laboratory studies demonstrated that the reactive uptake of photooxidation products of isoprene, particularly IEPOX, in the presence of acidic particles contribute to the $m / z 82$ signal detected by the AMS (Lin et al., 2012; Budisulistiorini et al., 2013; Liu et al., 2014). Even so, the spectra of isoprene SOM or IEPOX SOM produced in the laboratory have some important differences compared to the statistical factors (i.e., "OOA-2" of this study and "82Fac", "UNKN", and "IEPOX-OA" of earlier studies) derived from atmospheric data sets. In particular, there are significant differences at $\mathrm{m} / z 29$ and $\mathrm{m} / z 39$ through $\mathrm{m} / z$ 44. The values of $f_{44}$ of the laboratory results are approximately $25 \%$ of those of the cited PMF factors. One possible explanation for these differences is that the laboratory experiments did not capture the full range of atmospheric processes, such as possible syn- 


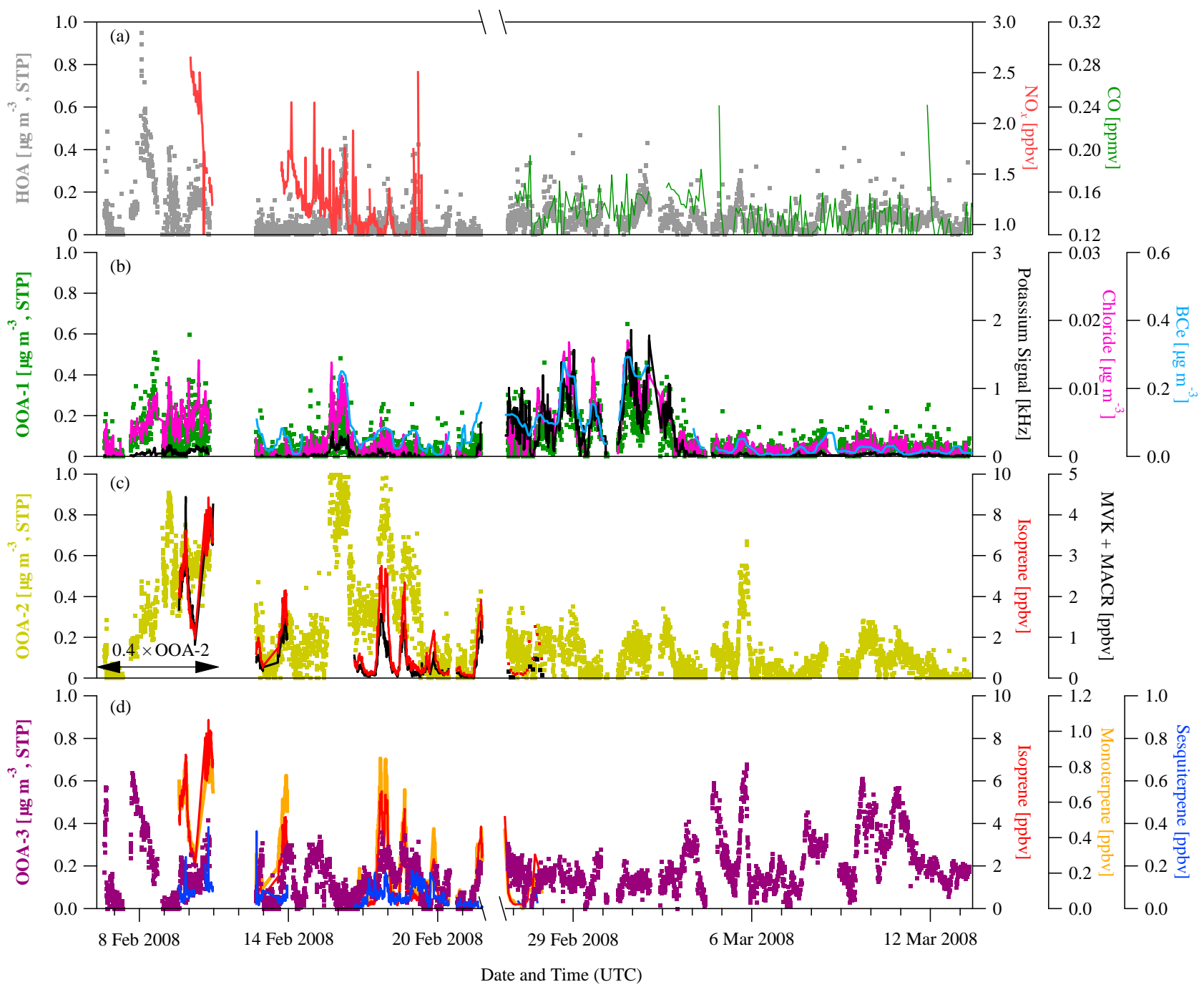

Figure 6. Time series of the loadings for the factors HOA, OOA-1, OOA-2, and OOA-3 (left axes; dots) and time series of the concentrations of tracer species, including $\mathrm{NO}_{\mathrm{x}}, \mathrm{CO}$, AMS chloride, AMS potassium, aethalometer black carbon, MVK + MACR, isoprene, monoterpenes, and sesquiterpenes (right axes; lines). The BVOCs were measured by proton-transfer-reaction mass spectrometry (PTR-MS; Karl et al., 2009).

ergistic chemistry among the range of atmospheric precursors, aqueous-phase processing, and photochemistry under a range of $\mathrm{HO}_{2}$ : $\mathrm{NO}$ ratios (Ervens et al., 2011; Emanuelsson et al., 2013; Liu et al., 2013; Nguyen et al., 2014). In particular, the laboratory experiments were typically carried out at low relative humidity. The atmosphere during AMAZE08 was humid (89-100\% RH; 25-75\% quantiles). Pöhlker et al. (2012) showed evidence of multiphase processing in the larger accumulation-mode particles. The oxidized material produced by aqueous-phase oxidation (e.g., dicarboxylic acids; Lim et al., 2010) may explain the higher $f_{44}$ in the OOA-2 factor compared to the laboratory spectra. In summary, the OOA-2 factor during AMAZE-08 was interpreted as SOM produced by the reactive uptake of isoprene pho- tooxidation products, including possible aqueous-phase oxidation in haze, fog, and cloud droplets.

The OOA-3 factor had a prominent peak at $\mathrm{m} / z 43$ (Fig. 5d). For $m / z>80$, the most intense peak occurred at $\mathrm{m} / z$ 91. The OOA-3 factor had similarities to the mass spectra recorded for biogenic SOM produced under conditions relevant to the Amazon Basin. Specifically, SOM produced from isoprene under laboratory conditions had a prominent peak at $m / z 43$ (Fig. 4a). Mass spectra of SOM derived from precursors of monoterpene $\alpha$-pinene and sesquiterpene $\beta$ caryophyllene had similar patterns as OOA-3 at $m / z 55$ and $m / z$ 91. A linear combination of the three chamber spectra largely reproduced the OOA-3 factor (Fig. 7; 50\% isoprenederived SOM, $30 \% \alpha$-pinene-derived SOM, and $20 \% \beta$ caryophyllene-derived SOM). The intensity at $m / z$ 29, how- 


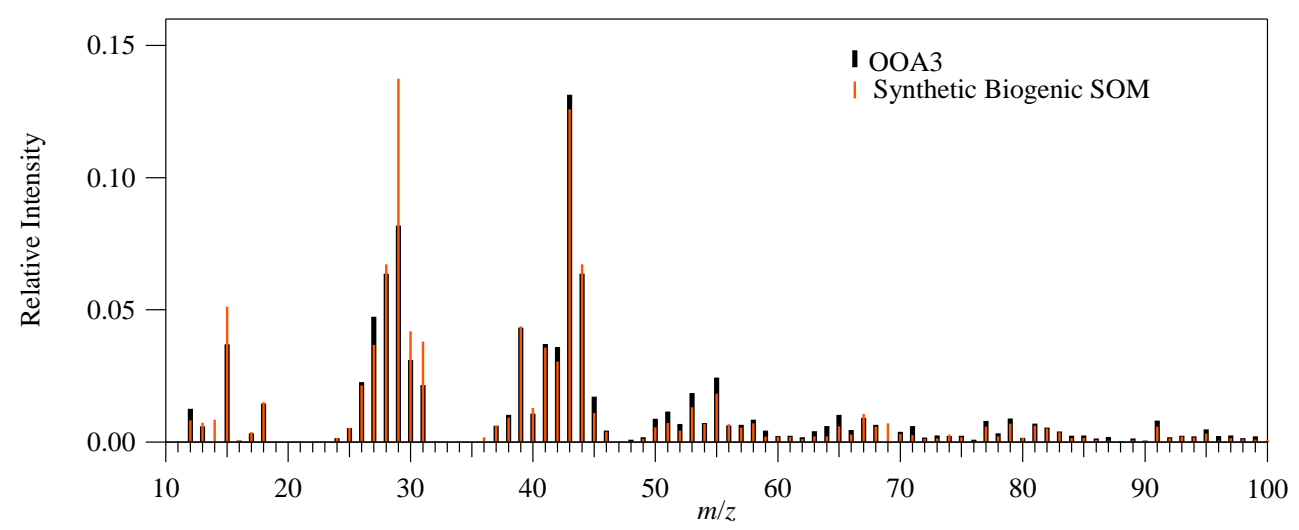

Figure 7. Comparison of the OOA-3 factor to a synthetic mass spectrum obtained from a linear combination of the mass spectra of laboratorygenerated biogenic SOM (30\% $\alpha$-pinene-derived SOM, $20 \% \beta$-caryophyllene-derived SOM, and $50 \%$ isoprene-derived SOM at mass concentrations of 0.4 to $0.7 \mu \mathrm{g} \mathrm{m}^{-3}$ ).

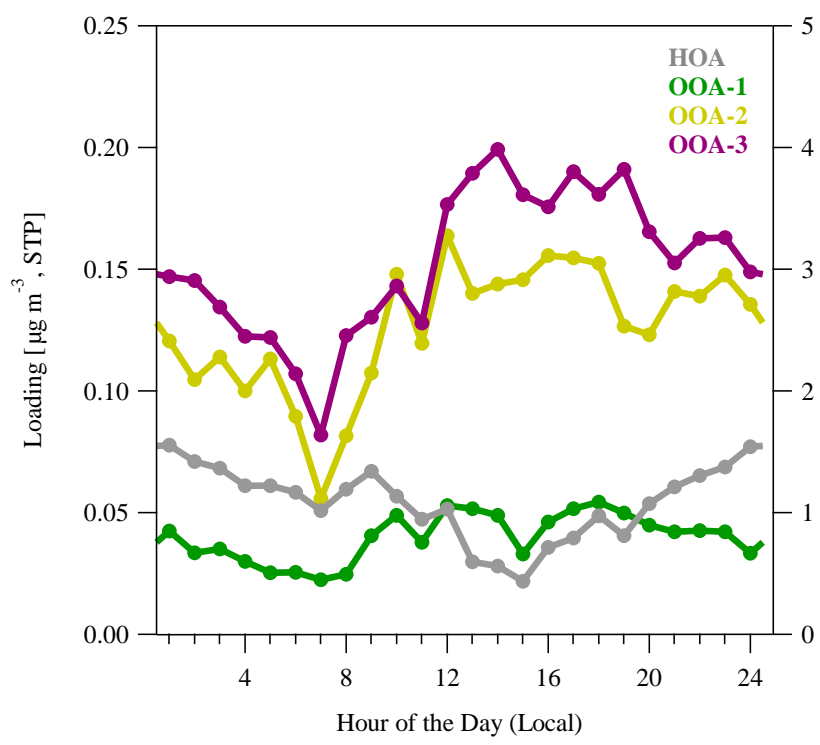

Figure 8. Campaign-average diel profiles of the loadings of the factors HOA, OOA-1, OOA-2, and OOA-3.

ever, was overestimated by the linear combination. The remarkable result is that the ambient factor could, to a large extent, be explained by just three laboratory data sets, given the wide range of BVOC precursor compounds that can contribute to SOM production in the Amazon Basin. The explanation is 3-fold: (1) isoprene is the dominant BVOC for this rain forest; (2) the AMS breaks complex molecules into simpler building blocks by electron-impact ionization; and (3) the higher-order $\mathrm{C}_{10}, \mathrm{C}_{15}$, and possibly $\mathrm{C}_{20}$ BVOCs are all assembled biochemically from the isoprene $\left(\mathrm{C}_{5}\right)$ monomer. Moreover, the temporal variation in the OOA-3 loading tracked that of the BVOC concentrations (Fig. 6d). The OOA-3 statistical factor was therefore interpreted as associated with freshly produced SOM similar to that produced in the chamber experiments, meaning on a timescale of several hours by a mechanism of gas-to-particle partitioning of the BVOC oxidation products.

Figure 8 shows the campaign-average diel profiles of the factor loadings. The HOA loading had a daytime minimum, suggesting the buildup of local pollution during the night and the removal by convective mixing during the day. In support of this interpretation, the nocturnal boundary layer was approximately $100 \mathrm{~m}$ or less. At daybreak, the boundary layer rapidly developed, reaching on the order of $1000 \mathrm{~m}$ by local noon around the site (Martin et al., 2010b). The OOA-1 loading peaked around noon without great variation throughout the day. This temporal behavior is expected for homogeneous mixing in the atmospheric column without in situ sources, such as for material arriving by long-range transport. The small daytime increase was consistent with the daytime convective downward mixing of older, oxidized particles from aloft. By comparison, the OOA-2 and OOA-3 loadings peaked in the early afternoon while the BVOC concentrations were high (cf. Fig. 3c of Chen et al., 2009). This temporal behavior was consistent with the photochemically driven production of SOM.

Figure 9 shows the time series of fractional contribution by each of the four statistical factors identified by PMF analysis. On average the relative loadings of HOA, OOA-1, OOA2 , and OOA-3 were 14, 14, 34, and 38, respectively. For comparison, other studies reported $0-21 \%$ of HOA for remote locations (Jimenez et al., 2009) and 23-50\% of OOA-2 (called "82Fac", "UNKN", and "IEPOX-OA" in earlier studies; Robinson et al., 2011; Slowik et al., 2011; Budisulistiorini et al., 2013). Figure 9 shows that the relative importance of each process as a contributor differed with time and highlights two focus periods. Precipitation and temperature were the major meteorological factors that differed between the two periods. The first period was sunny and warmer, with occasional clouds, and the second period had frequent heavy rainfall events. Long-range back-trajectory analyses 


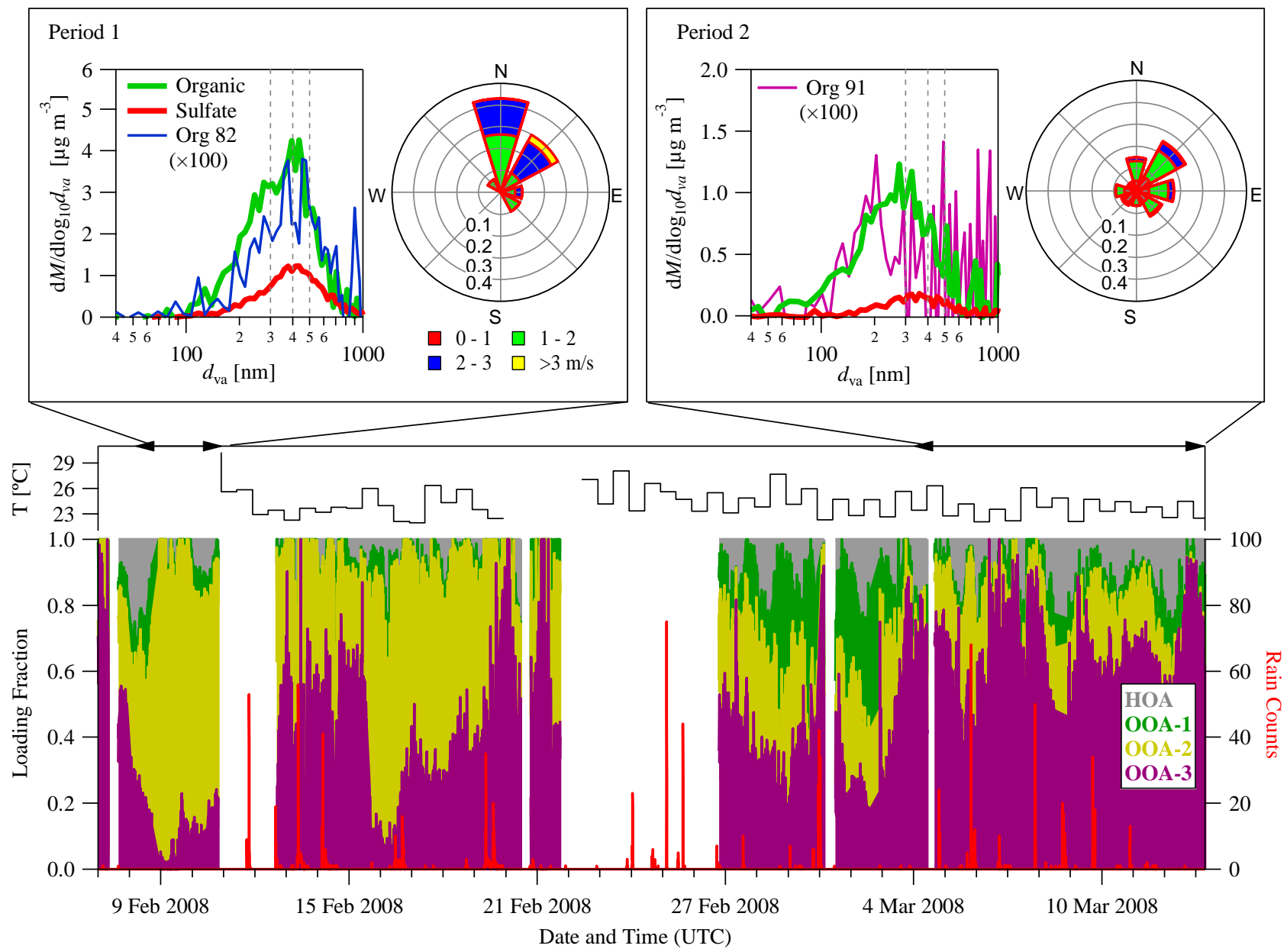

Figure 9. Top: mass-diameter distributions measured by the AMS and the daytime wind rose for the two time periods shown in the bottom panel. Upper section, bottom panel: time series of daily mean temperature measured at the top of the measurement tower TT34. Lower section, bottom panel: time series of the fractional contribution by each of the four statistical factors identified by PMF analysis (left axes) and the rain counts (right axes). Two case periods that differ significantly in the fractional contribution of PMF factors are selected.

presented in Martin et al. (2010b) showed that the air masses consistently arrived from the equatorial Atlantic Ocean passing as northeasterlies through the Amazon Basin. Local measurements showed that the daytime winds mainly came from the north and northeast (Fig. 9, top). During the first period, the average fractional contribution by the OOA-2 factor was 5 times greater than that of the OOA-3 factor. During the second period, by comparison, the fractional contribution by the OOA-3 factor was 3 times greater than that of the OOA-2 factor. The average organic-mass concentrations of the two periods were 1.84 and $0.59 \mathrm{\mu g} \mathrm{m}^{-3}$, respectively.

Figure 9 shows that the loading fraction of the OOA-2 factor consistently dropped following heavy rainfall events, suggesting more efficient in-cloud or below-cloud scavenging for the types of material represented by OOA-2 than for those types represented by OOA-3. This finding further supports the interpretation that the OOA-2 factor represents, at least in part, aqueous-phase production pathways because SOM produced in this way has greater water solubility and hence greater wet-deposition rates than SOM produced freshly by gas-to-particle condensation, as suggested for the OOA-3 factor. Figure 9 also shows that the mode diameter of organic material in period 1 , which has a higher OOA-2 loading fraction, is significantly larger than that in period 2 , which has a higher OOA-3 loading fraction. Aqueous-phase processing is anticipated to add additional organic material that results in larger mode diameters after dehydration.

\section{Conclusions}

Submicron particle mass concentration in the Amazonian rainforest during the wet season of 2008 was dominated by organic material. The environment was humid, $\mathrm{HO}_{2}-$ dominant and isoprene-rich, with the presence of acidic particles in the submicron fraction of the atmospheric particle population. Factors OOA-2 and OOA-3 were identified in the 
patterns of the collected mass spectra. These factors were interpreted as tied to the in-basin production of biogenic secondary organic material and together accounted for $>70 \%$ of the factor loadings, with the balance from HOA and OOA-1. The OOA-2 factor was implicated as associated with the reactive uptake of isoprene oxidation products, especially of epoxydiols to acidic haze, fog, or cloud droplets. The OOA3 factor was consistent with an association with the fresh production of SOM by a mechanism of gas-phase oxidation of BVOCs followed by gas-to-particle conversion of the oxidation products. Although multivariate statistical factors do not correspond to segregated individual chemical components (e.g., unlike molecules or families of molecules), the factors nevertheless can be indicative of the relative importance of different atmospheric emissions and process pathways. With this caveat in mind, the PMF analysis herein finds that the factor loadings had, on average, a ratio of $1.4: 1$ for OOA-2 compared to OOA-3 and were alternately dominated in different periods of AMAZE- 08 by the OOA- 2 and OOA-3. These findings suggest a comparable importance of gas-phase and particle-phase (including haze, fog, and cloud droplets) production of SOM during the study period.

\section{The Supplement related to this article is available online at doi:10.5194/acp-15-3687-2015-supplement.}

Acknowledgements. Support was received from the USA National Science Foundation, the German Max Planck Society, and Brazilian CNPq and FAPESP agencies. Q. Chen acknowledges a NASA Earth and Space Science Fellowship. D. K. Farmer acknowledges an NOAA Global Change Fellowship. T. Pauliquevis acknowledges the CNPq grant 552831/2006-9. P. Artaxo acknowledges FAPESP projects 2008/58100-2, 2010/52658-1, 2011/50170-4, and 2012/14437-9. We thank the INPA LBA central office in Manaus for logistical support during AMAZE-08. We thank John Jayne, Joel Kimmel, Niall Robinson, Johannes Schneider, and Soeren Zorn for helping with sampling and aspects of data analysis.

Edited by: W. Maenhaut

\section{References}

Ahlm, L., Nilsson, E. D., Krejci, R., Mårtensson, E. M., Vogt, M., and Artaxo, P.: Aerosol number fluxes over the Amazon rain forest during the wet season, Atmos. Chem. Phys., 9, 9381-9400, doi:10.5194/acp-9-9381-2009, 2009.

Aiken, A. C., Decarlo, P. F., Kroll, J. H., Worsnop, D. R., Huffman, J. A., Docherty, K. S., Ulbrich, I. M., Mohr, C., Kimmel, J. R., Sueper, D., Sun, Y., Zhang, Q., Trimborn, A., Northway, M., Ziemann, P. J., Canagaratna, M. R., Onasch, T. B., Alfarra, M. R., Prevot, A. S. H., Dommen, J., Duplissy, J., Metzger, A., Baltensperger, U., and Jimenez, J. L.: O/C and OM/OC ratios of primary, secondary, and ambient organic aerosols with highresolution time-of-flight aerosol mass spectrometry, Environ. Sci. Technol., 42, 4478-4485, doi:10.1021/es703009q, 2008.

Andreae, M. O.: Aerosols before pollution, Science, 315, 50-51, doi:10.1126/science.1136529, 2007.

Andreae, M. O., Berresheim, H., Bingemer, H., Jacob, D. J., Lewis, B. L., Li, S. M., and Talbot, R. W.: The atmospheric sulfur cycle over the Amazon Basin: 2 - Wet season, J. Geophys. Res., 95, 16813-16824, 1990.

Baars, H., Ansmann, A., Althausen, D., Engelmann, R., Artaxo, P., Pauliquevis, T., and Souza, R.: Further evidence for significant smoke transport from Africa to Amazonia, Geophys. Res. Lett., 38, L20802, doi:10.1029/2011GL049200, 2011.

Ben-Ami, Y., Koren, I., Rudich, Y., Artaxo, P., Martin, S. T., and Andreae, M. O.: Transport of North African dust from the Bodélé depression to the Amazon Basin: a case study, Atmos. Chem. Phys., 10, 7533-7544, doi:10.5194/acp-10-7533-2010, 2010.

Budisulistiorini, S. H., Canagaratna, M. R., Croteau, P. L., Marth, W. J., Baumann, K., Edgerton, E. S., Shaw, S. L., Knipping, E. M., Worsnop, D. R., Jayne, J. T., Gold, A., and Surratt, J. D.: Real-time continuous characterization of secondary organic aerosol derived from isoprene epoxydiols in downtown Atlanta, Georgia, using the Aerodyne aerosol chemical speciation monitor, Environ. Sci. Technol., 47, 5686-5694, doi:10.1021/es400023n, 2013.

Canagaratna, M. R., Jayne, J. T., Ghertner, D. A., Herndon, S., Shi, Q., Jimenez, J. L., Silva, P. J., Williams, P., Lanni, T., Drewnick, F., Demerjian, K. L., Kolb, C. E., and Worsnop, D. R.: Chase studies of particulate emissions from in-use New York City vehicles, Aerosol Sci. Technol., 38, 555-573, doi:10.1080/02786820490465504, 2004.

Canagaratna, M. R., Jimenez, J. L., Kroll, J. H., Chen, Q., Kessler, S. H., Massoli, P., Hildebrandt Ruiz, L., Fortner, E., Williams, L. R., Wilson, K. R., Surratt, J. D., Donahue, N. M., Jayne, J. T., and Worsnop, D. R.: Elemental ratio measurements of organic compounds using aerosol mass spectrometry: characterization, improved calibration, and implications, Atmos. Chem. Phys., 15, 253-272, doi:10.5194/acp-15-253-2015, 2015.

Chen, Q., Farmer, D. K., Schneider, J., Zorn, S. R., Heald, C. L., Karl, T. G., Guenther, A., Allan, J. D., Robinson, N., Coe, H., Kimmel, J. R., Pauliquevis, T., Borrmann, S., Pöschl, U., Andreae, M. O., Artaxo, P., Jimenez, J. L., and Martin, S. T.: Mass spectral characterization of submicron biogenic organic particles in the Amazon Basin, Geophys. Res. Lett., 36, L20806, doi:10.1029/2009g1039880, 2009.

Chen, Q., Liu, Y., Donahue, N. M., Shilling, J. E., and Martin, S. T.: Particle-phase chemistry of secondary organic material: Modeled compared to measured $\mathrm{O}: \mathrm{C}$ and $\mathrm{H}: \mathrm{C}$ elemental ratios provide constraints, Environ. Sci. Technol., 45, 4763-4770, doi:10.1021/es104398s, 2011.

Chen, Q., Li, Y. L., McKinney, K. A., Kuwata, M., and Martin, S. T.: Particle mass yield from $\beta$-caryophyllene ozonolysis, Atmos. Chem. Phys., 12, 3165-3179, doi:10.5194/acp-12-31652012, 2012.

Chirico, R., DeCarlo, P. F., Heringa, M. F., Tritscher, T., Richter, R., Prévôt, A. S. H., Dommen, J., Weingartner, E., Wehrle, G., Gysel, M., Laborde, M., and Baltensperger, U.: Impact of aftertreatment devices on primary emissions and secondary organic aerosol formation potential from in-use diesel vehicles: re- 
sults from smog chamber experiments, Atmos. Chem. Phys., 10, 11545-11563, doi:10.5194/acp-10-11545-2010, 2010.

Docherty, K. S., Aiken, A. C., Huffman, J. A., Ulbrich, I. M., DeCarlo, P. F., Sueper, D., Worsnop, D. R., Snyder, D. C., Peltier, R. E., Weber, R. J., Grover, B. D., Eatough, D. J., Williams, B. J., Goldstein, A. H., Ziemann, P. J., and Jimenez, J. L.: The 2005 Study of Organic Aerosols at Riverside (SOAR-1): instrumental intercomparisons and fine particle composition, Atmos. Chem. Phys., 11, 12387-12420, doi:10.5194/acp-11-12387-2011, 2011.

Ehn, M., Thornton, J. A., Kleist, E., Sipila, M., Junninen, H., Pullinen, I., Springer, M., Rubach, F., Tillmann, R., Lee, B., LopezHilfiker, F., Andres, S., Acir, I. H., Rissanen, M., Jokinen, T., Schobesberger, S., Kangasluoma, J., Kontkanen, J., Nieminen, T., Kurten, T., Nielsen, L. B., Jorgensen, S., Kjaergaard, H. G., Canagaratna, M., Dal Maso, M., Berndt, T., Petaja, T., Wahner, A., Kerminen, V. M., Kulmala, M., Worsnop, D. R., Wildt, J., and Mentel, T. F.: A large source of low-volatility secondary organic aerosol, Nature, 506, 476-479, doi:10.1038/nature13032, 2014.

Elbert, W., Taylor, P. E., Andreae, M. O., and Pöschl, U.: Contribution of fungi to primary biogenic aerosols in the atmosphere: wet and dry discharged spores, carbohydrates, and inorganic ions, Atmos. Chem. Phys., 7, 4569-4588, doi:10.5194/acp-7-4569-2007, 2007.

Emanuelsson, E. U., Hallquist, M., Kristensen, K., Glasius, M., Bohn, B., Fuchs, H., Kammer, B., Kiendler-Scharr, A., Nehr, S., Rubach, F., Tillmann, R., Wahner, A., Wu, H.-C., and Mentel, Th. F.: Formation of anthropogenic secondary organic aerosol (SOA) and its influence on biogenic SOA properties, Atmos. Chem. Phys., 13, 2837-2855, doi:10.5194/acp-13-2837-2013, 2013.

Ervens, B., Turpin, B. J., and Weber, R. J.: Secondary organic aerosol formation in cloud droplets and aqueous particles (aqSOA): a review of laboratory, field and model studies, Atmos. Chem. Phys., 11, 11069-11102, doi:10.5194/acp-1111069-2011, 2011

Fuzzi, S., Decesari, S., Facchini, M. C., Cavalli, F., Emblico, L., Mircea, M., Andreae, M. O., Trebs, I., Hoffer, A., Guyon, P., Artaxo, P., Rizzo, L. V., Lara, L. L., Pauliquevis, T., Maenhaut, W., Raes, N., Chi, X. G., Mayol-Bracero, O. L., Soto-Garcia, L. L., Claeys, M., Kourtchev, I., Rissler, J., Swietlicki, E., Tagliavini, E., Schkolnik, G., Falkovich, A. H., Rudich, Y., Fisch, G., and Gatti, L. V.: Overview of the inorganic and organic composition of size-segregated aerosol in Rondonia, Brazil, from the biomassburning period to the onset of the wet season, J. Geophys. Res., 112, D01201, doi:10.1029/2005JD006741, 2007.

Gerab, F., Artaxo, P., Gillett, R., and Ayers, G.: PIXE, PIGE and ion chromatography of aerosol particles from northeast Amazon Basin, Nucl. Instrum. Meth. B, 136, 955-960, 1998.

Graham, B., Guyon, P., Taylor, P. E., Artaxo, P., Maenhaut, W., Glovsky, M. M., Flagan, R. C., and Andreae, M. O.: Organic compounds present in the natural Amazonian aerosol: Characterization by gas chromatography-mass spectrometry, J. Geophys. Res., 108, 4766, doi:10.1029/2003jd003990, 2003a.

Graham, B., Guyon, P., Maenhaut, W., Taylor, P. E., Ebert, M., Matthias-Maser, S., Mayol-Bracero, O. L., Godoi, R. H. M., Artaxo, P., Meixner, F. X., Moura, M. A. L., Rocha, C., Van Grieken, R., Glovsky, M. M., Flagan, R. C., and Andreae, M. O.: Composition and diurnal variability of the natural Amazonian aerosol, J. Geophys. Res., 108, 4765, doi:10.1029/2003JD004049, 2003b.
Gunthe, S. S., King, S. M., Rose, D., Chen, Q., Roldin, P., Farmer, D. K., Jimenez, J. L., Artaxo, P., Andreae, M. O., Martin, S. T., and Pöschl, U.: Cloud condensation nuclei in pristine tropical rainforest air of Amazonia: size-resolved measurements and modeling of atmospheric aerosol composition and CCN activity, Atmos. Chem. Phys., 9, 7551-7575, doi:10.5194/acp-9-75512009, 2009.

He, L.-Y., Lin, Y., Huang, X.-F., Guo, S., Xue, L., Su, Q., Hu, M., Luan, S.-J., and Zhang, Y.-H.: Characterization of highresolution aerosol mass spectra of primary organic aerosol emissions from Chinese cooking and biomass burning, Atmos. Chem Phys., 10, 11535-11543, doi:10.5194/acp-10-11535-2010, 2010.

IPCC: Climate Change 2013: The Physical Science Basis, in: Contribution of Working Group I to the Fifth Assessment Report of the Intergovernmental Panel on Climate Change, edited by: Stocker, T. F., Qin, D., Plattner, G.-K., Tignor, M., Allen, S. K., Boschung, J., Nauels, A., Xia, Y., Bex, V., and Midgley, P. M., Cambridge University Press, Cambridge, United Kingdom and New York, NY, USA, 1535 pp., 2013.

Jimenez, J. L., Canagaratna, M. R., Donahue, N. M., Prevot, A. S. H., Zhang, Q., Kroll, J. H., DeCarlo, P. F., Allan, J. D., Coe, H., Ng, N. L., Aiken, A. C., Docherty, K. S., Ulbrich, I. M., Grieshop, A. P., Robinson, A. L., Duplissy, J., Smith, J. D., Wilson, K. R., Lanz, V. A., Hueglin, C., Sun, Y. L., Tian, J., Laaksonen, A., Raatikainen, T., Rautiainen, J., Vaattovaara, P., Ehn, M., Kulmala, M., Tomlinson, J. M., Collins, D. R., Cubison, M. J., Dunlea, E. J., Huffman, J. A., Onasch, T. B., Alfarra, M. R., Williams, P. I., Bower, K., Kondo, Y., Schneider, J., Drewnick, F., Borrmann, S., Weimer, S., Demerjian, K., Salcedo, D., Cottrell, L., Griffin, R., Takami, A., Miyoshi, T., Hatakeyama, S., Shimono, A., Sun, J. Y., Zhang, Y. M., Dzepina, K., Kimmel, J. R., Sueper, D., Jayne, J. T., Herndon, S. C., Trimborn, A. M., Williams, L. R., Wood, E. C., Middlebrook, A. M., Kolb, C. E., Baltensperger, U., and Worsnop, D. R.: Evolution of organic aerosols in the atmosphere, Science, 326, 1525-1529, doi:10.1126/science.1180353, 2009.

Karl, T., Guenther, A., Turnipseed, A., Tyndall, G., Artaxo, P., and Martin, S.: Rapid formation of isoprene photo-oxidation products observed in Amazonia, Atmos. Chem. Phys., 9, 7753-7767, doi:10.5194/acp-9-7753-2009, 2009.

King, S. M., Rosenoern, T., Shilling, J. E., Chen, Q., Wang, Z., Biskos, G., McKinney, K. A., Pöschl, U., and Martin, S. T.: Cloud droplet activation of mixed organic-sulfate particles produced by the photooxidation of isoprene, Atmos. Chem. Phys., 10, 3953-3964, doi:10.5194/acp-10-3953-2010, 2010.

Kuhn, U., Ganzeveld, L., Thielmann, A., Dindorf, T., Schebeske, G., Welling, M., Sciare, J., Roberts, G., Meixner, F. X., Kesselmeier, J., Lelieveld, J., Kolle, O., Ciccioli, P., Lloyd, J., Trentmann, J., Artaxo, P., and Andreae, M. O.: Impact of Manaus City on the Amazon Green Ocean atmosphere: ozone production, precursor sensitivity and aerosol load, Atmos. Chem. Phys., 10, 9251-9282, doi:10.5194/acp-10-9251-2010, 2010.

Lambe, A. T., Onasch, T. B., Massoli, P., Croasdale, D. R., Wright, J. P., Ahern, A. T., Williams, L. R., Worsnop, D. R., Brune, W. H., and Davidovits, P.: Laboratory studies of the chemical composition and cloud condensation nuclei (CCN) activity of secondary organic aerosol (SOA) and oxidized primary organic aerosol (OPOA), Atmos. Chem. Phys., 11, 8913-8928, doi:10.5194/acp11-8913-2011, 2011. 
Lim, Y. B., Tan, Y., Perri, M. J., Seitzinger, S. P., and Turpin, B. J.: Aqueous chemistry and its role in secondary organic aerosol (SOA) formation, Atmos. Chem. Phys., 10, 1052110539, doi:10.5194/acp-10-10521-2010, 2010.

Lin, Y. H., Zhang, Z. F., Docherty, K. S., Zhang, H. F., Budisulistiorini, S. H., Rubitschun, C. L., Shaw, S. L., Knipping, E. M., Edgerton, E. S., Kleindienst, T. E., Gold, A., and Surratt, J. D.: Isoprene epoxydiols as precursors to secondary organic aerosol formation: acid-catalyzed reactive uptake studies with authentic compounds, Environ. Sci. Technol., 46, 250-258, doi:10.1021/es202554c, 2012.

Liu, Y. J., Herdlinger-Blatt, I., McKinney, K. A., and Martin, S. T.: Production of methyl vinyl ketone and methacrolein via the hydroperoxyl pathway of isoprene oxidation, Atmos. Chem. Phys., 13, 5715-5730, doi:10.5194/acp-13-5715-2013, 2013.

Liu, Y., Kuwata, M., Strick, B. F., Geiger, F. M., Thomson, R. J., McKinney, K. A., and Martin, S. T.: Uptake of epoxydiol isomers accounts for half of the particle-phase material produced from isoprene photooxidation via the $\mathrm{HO}_{2}$ pathway, Environ. Sci. Technol., 49, 250-258, doi:10.1021/es5034298, 2014.

Malm, W. C., Sisler, J. F., Huffman, D., Eldred, R. A., and Cahill, T. A.: Spatial and seasonal trends in particle concentration and optical extinction in the united states, J. Geophys. Res., 99, 13471370, 1994.

Martin, S. T., Andreae, M. O., Artaxo, P., Baumgardner, D., Chen, Q., Goldstein, A. H., Guenther, A., Heald, C. L., Mayol-Bracero, O. L., McMurry, P. H., Pauliquevis, T., Pöschl, U., Prather, K. A., Roberts, G. C., Saleska, S. R., Dias, M. A. S., Spracklen, D. V., Swietlicki, E., and Trebs, I.: Sources and properties of amazonian aerosol particles, Rev. Geophys., 48, RG2002, doi:10.1029/2008rg000280, 2010a.

Martin, S. T., Andreae, M. O., Althausen, D., Artaxo, P., Baars, H., Borrmann, S., Chen, Q., Farmer, D. K., Guenther, A., Gunthe, S. S., Jimenez, J. L., Karl, T., Longo, K., Manzi, A., Müller, T., Pauliquevis, T., Petters, M. D., Prenni, A. J., Pöschl, U., Rizzo, L. V., Schneider, J., Smith, J. N., Swietlicki, E., Tota, J., Wang, J., Wiedensohler, A., and Zorn, S. R.: An overview of the Amazonian Aerosol Characterization Experiment 2008 (AMAZE08), Atmos. Chem. Phys., 10, 11415-11438, doi:10.5194/acp10-11415-2010, 2010b.

Matthew, B. M., Middlebrook, A. M., and Onasch, T. B.: Collection efficiencies in an Aerodyne aerosol mass spectrometer as a function of particle phase for laboratory generated aerosols, Aerosol Sci. Technol., 42, 884-898, doi:10.1080/02786820802356797, 2008.

Ng, N. L., Canagaratna, M. R., Zhang, Q., Jimenez, J. L., Tian, J., Ulbrich, I. M., Kroll, J. H., Docherty, K. S., Chhabra, P. S., Bahreini, R., Murphy, S. M., Seinfeld, J. H., Hildebrandt, L., Donahue, N. M., DeCarlo, P. F., Lanz, V. A., Prévôt, A. S. H., Dinar, E., Rudich, Y., and Worsnop, D. R.: Organic aerosol components observed in Northern Hemispheric datasets from Aerosol Mass Spectrometry, Atmos. Chem. Phys., 10, 46254641, doi:10.5194/acp-10-4625-2010, 2010.

Ng, N. L., Canagaratna, M. R., Jimenez, J. L., Chhabra, P. S., Seinfeld, J. H., and Worsnop, D. R.: Changes in organic aerosol composition with aging inferred from aerosol mass spectra, Atmos. Chem. Phys., 11, 6465-6474, doi:10.5194/acp-11-64652011, 2011.
Nguyen, T. B., Coggon, M. M., Bates, K. H., Zhang, X., Schwantes, R. H., Schilling, K. A., Loza, C. L., Flagan, R. C., Wennberg, P. O., and Seinfeld, J. H.: Organic aerosol formation from the reactive uptake of isoprene epoxydiols (IEPOX) onto nonacidified inorganic seeds, Atmos. Chem. Phys., 14, 3497-3510, doi:10.5194/acp-14-3497-2014, 2014.

Ortega, A. M., Day, D. A., Cubison, M. J., Brune, W. H., Bon, D., de Gouw, J. A., and Jimenez, J. L.: Secondary organic aerosol formation and primary organic aerosol oxidation from biomass-burning smoke in a flow reactor during FLAME-3, Atmos. Chem. Phys., 13, 11551-11571, doi:10.5194/acp-1311551-2013, 2013.

Paatero, P. and Tapper, U.: Positive matrix factorization a nonnegative factor model with optimal utilization of error-estimates of data values, Environmetrics, 5, 111-126, doi:10.1002/env.3170050203, 1994.

Pankow, J. F.: An absorption-model of the gas aerosol partitioning involved in the formation of secondary organic aerosol, Atmos. Environ., 28, 189-193, 1994.

Petzold, A., Kramer, H., and Schonlinner, M.: Continuous measurement of atmospheric black carbon using a multi-angle absorption photometer, Environ. Sci. Poll. Res., 4, 78-82, 2002.

Pöhlker, C., Wiedemann, K. T., Sinha, B., Shiraiwa, M., Gunthe, S. S., Smith, M., Su, H., Artaxo, P., Chen, Q., Cheng, Y. F., Elbert, W., Gilles, M. K., Kilcoyne, A. L. D., Moffet, R. C., Weigand, M., Martin, S. T., Poeschl, U., and Andreae, M. O.: Biogenic potassium salt particles as seeds for secondary organic aerosol in the Amazon, Science, 337, 1075-1078, doi:10.1126/science.1223264, 2012.

Pöschl, U., Martin, S. T., Sinha, B., Chen, Q., Gunthe, S. S., Huffman, J. A., Borrmann, S., Farmer, D. K., Garland, R. M., Helas, G., Jimenez, J. L., King, S. M., Manzi, A., Mikhailov, E., Pauliquevis, T., Petters, M. D., Prenni, A. J., Roldin, P., Rose, D., Schneider, J., Su, H., Zorn, S. R., Artaxo, P., and Andreae, M. O.: Rainforest aerosols as biogenic nuclei of clouds and precipitation in the Amazon, Science, 329, 1513-1516, doi:10.1126/science.1191056, 2010.

Prenni, A. J., Petters, M. D., Kreidenweis, S. M., Heald, C. L., Martin, S. T., Artaxo, P., Garland, R. M., Wollny, A. G., and Pöschl, U.: Relative roles of biogenic emissions and Saharan dust as ice nuclei in the Amazon basin, Nat. Geosci., 2, 401-404, doi:10.1038/Ngeo517, 2009.

Rizzo, L. V., Artaxo, P., Müller, T., Wiedensohler, A., Paixão, M., Cirino, G. G., Arana, A., Swietlicki, E., Roldin, P., Fors, E. O., Wiedemann, K. T., Leal, L. S. M., and Kulmala, M.: Long term measurements of aerosol optical properties at a primary forest site in Amazonia, Atmos. Chem. Phys., 13, 2391-2413, doi:10.5194/acp-13-2391-2013, 2013.

Robinson, N. H., Hamilton, J. F., Allan, J. D., Langford, B., Oram, D. E., Chen, Q., Docherty, K., Farmer, D. K., Jimenez, J. L., Ward, M. W., Hewitt, C. N., Barley, M. H., Jenkin, M. E., Rickard, A. R., Martin, S. T., McFiggans, G., and Coe, H.: Evidence for a significant proportion of Secondary Organic Aerosol from isoprene above a maritime tropical forest, Atmos. Chem. Phys., 11, 1039-1050, doi:10.5194/acp-11-1039-2011, 2011.

Schneider, J., Freutel, F., Zorn, S. R., Chen, Q., Farmer, D. K., Jimenez, J. L., Martin, S. T., Artaxo, P., Wiedensohler, A., and Borrmann, S.: Mass-spectrometric identification of primary biological particle markers and application to pristine submicron 
aerosol measurements in Amazonia, Atmos. Chem. Phys., 11, 11415-11429, doi:10.5194/acp-11-11415-2011, 2011.

Shilling, J. E., Chen, Q., King, S. M., Rosenoern, T., Kroll, J. H., Worsnop, D. R., DeCarlo, P. F., Aiken, A. C., Sueper, D., Jimenez, J. L., and Martin, S. T.: Loading-dependent elemental composition of $\beta$-pinene SOA particles, Atmos. Chem. Phys., 9, 771-782, doi:10.5194/acp-9-771-2009, 2009.

Slowik, J. G., Brook, J., Chang, R. Y.-W., Evans, G. J., Hayden, K., Jeong, C.-H., Li, S.-M., Liggio, J., Liu, P. S. K., McGuire, M., Mihele, C., Sjostedt, S., Vlasenko, A., and Abbatt, J. P. D.: Photochemical processing of organic aerosol at nearby continental sites: contrast between urban plumes and regional aerosol, Atmos. Chem. Phys., 11, 2991-3006, doi:10.5194/acp-11-29912011, 2011.

Surratt, J. D., Chan, A. W. H., Eddingsaas, N. C., Chan, M. N., Loza, C. L., Kwan, A. J., Hersey, S. P., Flagan, R. C., Wennberg, P. O., and Seinfeld, J. H.: Reactive intermediates revealed in secondary organic aerosol formation from isoprene, Proc. Natl. Acad. Sci. USA, 107, 6640-6645, doi:10.1073/pnas.0911114107, 2010.

Talbot, R. W., Andreae, M. O., Andreae, T. W., and Harriss, R. C.: Regional aerosol chemistry of the Amazon Basin during the dry season, J. Geophys. Res., 93, 1499-1508, 1988.

Talbot, R. W., Andreae, M. O., Berresheim, H., Artaxo, P., Garstang, M., Harriss, R. C., Beecher, K. M., and Li, S. M.: Aerosol chemistry during the wet season in central amazonia: The influence of long-range transport, J. Geophys. Res., 95, 16955-16969, 1990.
Trebs, I., Metzger, S., Meixner, F. X., Helas, G. N., Hoffer, A., Rudich, Y., Falkovich, A. H., Moura, M. A. L., da Silva, R. S., Artaxo, P., Slanina, J., and Andreae, M. O.: The $\mathrm{NH}_{4}^{+}-\mathrm{NO}_{3}^{-}$ $\mathrm{Cl}^{-}-\mathrm{SO}_{4}^{2-}-\mathrm{H}_{2} \mathrm{O}$ aerosol system and its gas phase precursors at a pasture site in the Amazon Basin: How relevant are mineral cations and soluble organic acids?, J. Geophys. Res., 110, D07303, doi:10.1029/2004JD005478, 2005.

Ulbrich, I. M., Canagaratna, M. R., Zhang, Q., Worsnop, D. R., and Jimenez, J. L.: Interpretation of organic components from Positive Matrix Factorization of aerosol mass spectrometric data, Atmos. Chem. Phys., 9, 2891-2918, doi:10.5194/acp-9-2891-2009, 2009.

Vaden, T. D., Imre, D., Beranek, J., Shrivastava, M., and Zelenyuk, A.: Evaporation kinetics and phase of laboratory and ambient secondary organic aerosol, Proc. Natl. Acad. Sci. USA, 108, 2190-2195, doi:10.1073/pnas.1013391108, 2011.

Zhang, Q., Alfarra, M. R., Worsnop, D. R., Allan, J. D., Coe, H., Canagaratna, M. R., and Jimenez, J. L.: Deconvolution and quantification of hydrocarbon-like and oxygenated organic aerosols based on aerosol mass spectrometry, Environ. Sci. Technol., 39, 4938-4952, doi:10.1021/es0485681, 2005.

Zhang, Q., Jimenez, J. L., Canagaratna, M. R., Ulbrich, I. M., Ng, N. L., Worsnop, D. R., and Sun, Y. L.: Understanding atmospheric organic aerosols via factor analysis of aerosol mass spectrometry: a review, Anal. Bioanal. Chem., 401, 3045-3067, doi:10.1007/s00216-011-5355-y, 2011. 